\title{
Industrial Disputes in the Construction Sector
}

L. J. Perry (Associate Professor, School of Finance and Economics, University of Technology, Sydney. Australia)

\section{ABSTRACT}

The Cole Royal Commission enquiry into the building and construction (abbreviated to 'construction') sector recommended controversial workplace-relation reforms for that sector. The recommended changes are likely to be enshrined in legislation within the year. The Commission drew on analyses of industrial disputes that focused, in the main, on quite recent experience. This paper attempts to give a broader historical perspective on disputes in that sector by considering the pattern of disputes for the entire post-World War II period. Accordingly, data on disputes and employees during the entire period are gathered from Australian Bureau of Statistics current and archived sources. These data are classified according to sector (construction versus non-construction) and analysed. It is found that the strike rate has, on average, been greater in the construction sector than in the non-construction sector. However, there have been periods during which disputes in the construction sector have been relatively low. The most recent period was during the period of the Accord (1983-96), during which the strike rate in the construction sector fell relatively strongly. The analysis of this relatively broad historical period draws attention, among other things, to the possibility that the sort of strategies employed during the Accord years strategies of cooperation and consensus building - may provide a more effective means of bringing industrial peace to the workplace relations scene of the construction sector than policies that are relatively confrontational.

Key words: Australia, construction, strikes, stoppages, Cole Royal Commission

\section{INTRODUCTION}

In July 2005, the Howard Coalition government gained a majority in the Senate. This majority will enable the government to implement a number of legislative changes which it has, in the past, been prevented from fully implementing. One area in which significant changes are expected is that of workplace relations. That sector of the labour market that is likely to be affected the most is the construction sector. Indeed, Federal Minister for Employment and Workplace Relations, Kevin Andrews, has indicated that reform in the construction sector will be first 'first cab off the rank' (Skully and Tingle, 2005, p. 4). The legislative changes recommended by the contentious Cole Royal Commission are expected to find legislative form and be ratified by the Senate in 2005. The Cole Royal Commission was established in 2001 to investigate workplace conflict in the construction sector and to recommend legislative changes that might remedy perceived workplace relations problems within that sector. Given the importance of likely future workplace relations changes designed essentially to reduce strikes ${ }^{1}$ and disquiet in the construction sector, this paper examines the broad history of industrial disputes in the construction sector.

The research method involves gathering both current and archived Australian Bureau of Statistics (ABS) data on industrial disputes,

\footnotetext{
${ }^{1}$ Strictly speaking, a strike is but one of the forms of an industrial dispute. The other form is a lockout. A strike involves workers refusing to supply their labour to employers. In practice it often involves the striking workers preventing other non-striking workers from working. A lockout involves an employer refusing to engage workers. Because it can be difficult at times to distinguish between a strike and a lockout, in part because both of the parties involved in the dispute are at least partly responsible, many statistics departments, such as the Australian Bureau of Statistics, do not distinguish between strikes and lockouts; they are simply lumped together as industria disputes. There is a general consensus that lockouts in Australia during the post-World War II period have been relatively rare. As a result, this paper uses the terms 'industrial dispute' and 'strike' interchangeably. For further discussion of lockouts in Australia see Briggs (2004).
} 
employee numbers and inflation. The data on industrial disputes and employees are then compiled into separate series for the construction sector and the rest of the economy. Once compiled the data are analysed.

The objectives of this paper are fourfold: firstly to give some background information on the current relative dimensions of the labour force and unionism in the construction sector, second to review briefly the controversial findings of the Cole Royal Commission into the building and construction sector, third to extend the shortterm focus of the Cole Royal Commission on industrial disputes so as to take a longer term perspective of the changing pattern of industrial disputes in the construction sector relative to the rest of the economy, and finally to review those factors that might help explain for the changing pattern of industrial disputes over time.

The balance of the paper consists of four main sections. The first section gives background data on current union membership numbers for the construction sector and the rest of the economy. The second section reviews the findings and recommendations of the Cole Commission Reports into the Australian construction sector. The third section examines the changing pattern of industrial disputes in the construction sector relative to the rest of the economy. And finally some concluding thoughts are offered.

\section{SOME BACKGROUND ON THE CONSTRUCTION SECTOR}

The construction sector accounted for 6.2 per cent of Australia's Gross Domestic Product (GDP) during 2004. Ten years earlier, it accounted for 5.5 per cent. ${ }^{2}$ Thus the relative importance of the construction sector has increased a little over the last decade. During August 2004, total employment in the construction sector in Australia was around 800 thousand persons. ${ }^{3}$ Of these, about 500 thousand were employees, of which around 120 thousand were members of trade unions. ${ }^{4}$ Trade unions density (the percentage of employees who are union members) was around 23 per cent (ignoring rounding errors). Trade union density in the construction sector was virtually the same as trade union density for Australia as

\footnotetext{
${ }^{2}$ ABS (2005a)

${ }^{3}$ ABS (2005b)

${ }^{4}$ ABS (2005c)
}

a whole, but somewhat higher than average private sector union density which was just over 17 per cent. ${ }^{5}$ Given that most employees in the construction sector are in the private sector, a comparison with the private sector union density rate is probably more appropriate; it suggests that construction sector union density is a little higher than average.

In the construction sector unionists earned more, on average, than non-unionists. During 2004, mean weekly earnings of full-time construction employees were about 13 per cent higher for unionists compared to non-unionists. For Australia as whole, mean weekly earnings of all full-time employees were about 5 per cent higher for unionists compared to non-unionists (ABS, 2005c).

\section{THE ROYAL COMMISSION INTO THE BUILDING AND CONSTRUCTION INDUSTRY}

The Royal Commission into the Building and Construction Industry was headed by Royal Commissioner the Honourable Terence Rhoderic Hudson Cole RFD QC. It is thus sometimes referred to as the Cole Royal Commission, or words to that effect. The Cole Royal Commission was established in 2001 and the final report was released by the government early in 2003 .

In essence, the report is critical of the workplace relations system embedded in the construction sector, which it argues has been responsible for relatively low productivity ${ }^{6}$ and lost production. The Report points out that if productivity growth in the construction sector were to match that of the rest of the market sector: 'economic modelling shows that the accumulated gain in real GDP between 2003 and 2010 would approximate $\$ 12$ billion. All industries would benefit from an increase in output as a result of the reduction in the cost of building and construction' (Cole Royal Commission, 2003, V1, p.3). The Report largely blames the unions within the sector, particularly the dominant union, the CFMEU (The Construction, Forestry, Mining and Energy Union), for low productivity and lost production. It recommends that the power of all

\footnotetext{
${ }^{5}$ Private sector and public sector union density were $17.4 \%$ and $46.4 \%$, respectively. The proportion of tota employees in the private sector was 83 per cent. See ABS (2005c)

${ }^{6}$ See Perry (2005) for further discussion of productivity growth and the Cole Report.
} 
unions within the sector be reduced by both (i) more rigorously policing existing legislation and (ii) by introducing a range of additional limitations on what unions in the building and construction sector can and cannot do. To police existing and proposed new legislation, the Report recommends the establishment of a special independent body which will ensure that all labour market participants 'comply with industrial, civil and criminal laws applicable to all Australians ... as well as industry specific laws applicable to this industry only' (Cole Commission Report, 2003, V1, p. 4).

The independent body is provisionally referred to in the Report as the Australian Building and Construction Commission (ABCC). Not only is it proposed that the $A B C C$ monitor the building and construction sector, but also that it enforce the law. The government has already established an interim body - a precursor essentially - of the ABCC. This interim body is the Building Industry Taskforce.

The Report, which consists of 23 volumes and around 7000 pages, found 392 instances of alleged unlawful conduct. Most of these acts occurred in Western Australia (234), Victoria (58) and Queensland (55). In the confidential $23^{\text {rd }}$ volume, it is reported that 98 incidents have been referred for further preliminary investigation.

While employer groups have offered qualified support for the thrust of the findings of the Cole Report, unions have, not surprisingly, been highly critical of the Report. They argue that the Report was politically motivated, in the sense that it was established by a government hostile to the union movement and intent on reducing union power and influence. They argue that most of the alleged unlawful actions were trivial incidents - analogous to a pedestrian jaywalking. They also argue that witnesses' testimony was too readily accepted on face value without union representatives being given the opportunity to test (i.e. challenge) the claims. Of the 392 incidents of alleged unlawful/inappropriate behaviour cited in the first 22 volumes, none have been pursued through the courts, presumably because of a lack of evidence and/or merit, and of the 92 referrable incidents from the confidential volume, about three quarters have been dropped, with one quarter still in process, as at mid-2004. (Maitland, 2005, pp. 6-7) ${ }^{7}$

From the government's point of view, militant unions are an impediment to orderly economic development. In the long run, the living standards of workers are not determined by the actions of unions, but rather by the productivity of capital and labour resources. The more flexible these capital and labour resources are in the production process, the greater will be output and greater will be the capacity of the economy to reward its workers. Unions tend to stifle labour market flexibility, particularly militant ones. In the Building and Construction sector union militancy is seen to be not only an obstacle to greater flexibility, but also at times unlawful. Thus there is a need for more rigorous monitoring and policing. This perception is reflected in the views of the Employment and Workplace Relations Minister, Kevin Andrews, for example, when he claimed:

We have got a building construction industry where thuggery and intimidation is rife, found by the Cole Royal Commission, found by the task force itself. In a situation where a small contractor to be able to work on a site, has to pay out $\$ 7,000$ for seven CFMEU T-shirts in order to be able to work on a site - $\$ 7,000$. Now, that's unacceptable and we are not going to accept that ... (Andrews, 2004)

Clearly, the findings of the Cole Commission have proven to be controversial. Those interested in the issues raised in the Report are encouraged to refer to the report itself, which is freely available on the internet. Given the sheer volume of the report, a number of briefer commentaries by Moore (2004), Dabscheck (2003) and Marr (2003) may be of interest.

\section{INDUSTRIAL DISPUTE STATISTICS FOR THE BUILDING AND CONSTRUCTION SECTOR}

One of the principal reasons for establishing the Cole Commission was to address the issue of strikes in the building and construction industry, but in particular unlawful strikes and/or unlawful actions resulting in strikes. Most of the detailed

\footnotetext{
${ }^{7}$ For further commentary see Official Committee Hansard (2004) and Dabscheck (2003).
} 
statistical analysis of industrial disputes does not appear (in full) in the Report itself. Instead, a number of the discussion papers, particularly papers 2, 3 and 17, provide information in this regard. ${ }^{8}$ The Report does however review the circumstances surrounding a number of specific industrial disputes.

In this section we augment the Cole Commission background analyses of strikes by reviewing a longer timeframe than that of the discussion papers so as to give a broader historical perspective on matters.
Strike activity can be measured by the number of working days lost due to industrial disputes per thousand employees. This can be referred to as the strike rate. To give an immediate overview of the pattern of strikes during these post-World War II years, Figure 1 charts two series. The light line charts the strike rate for the construction sector. The heavy line charts the strike rate for the rest of the economy, or the non-construction sector. It is evident from Figure 1 that the strike rates in the construction sector and the non-construction sector have varied quite considerably over the years.

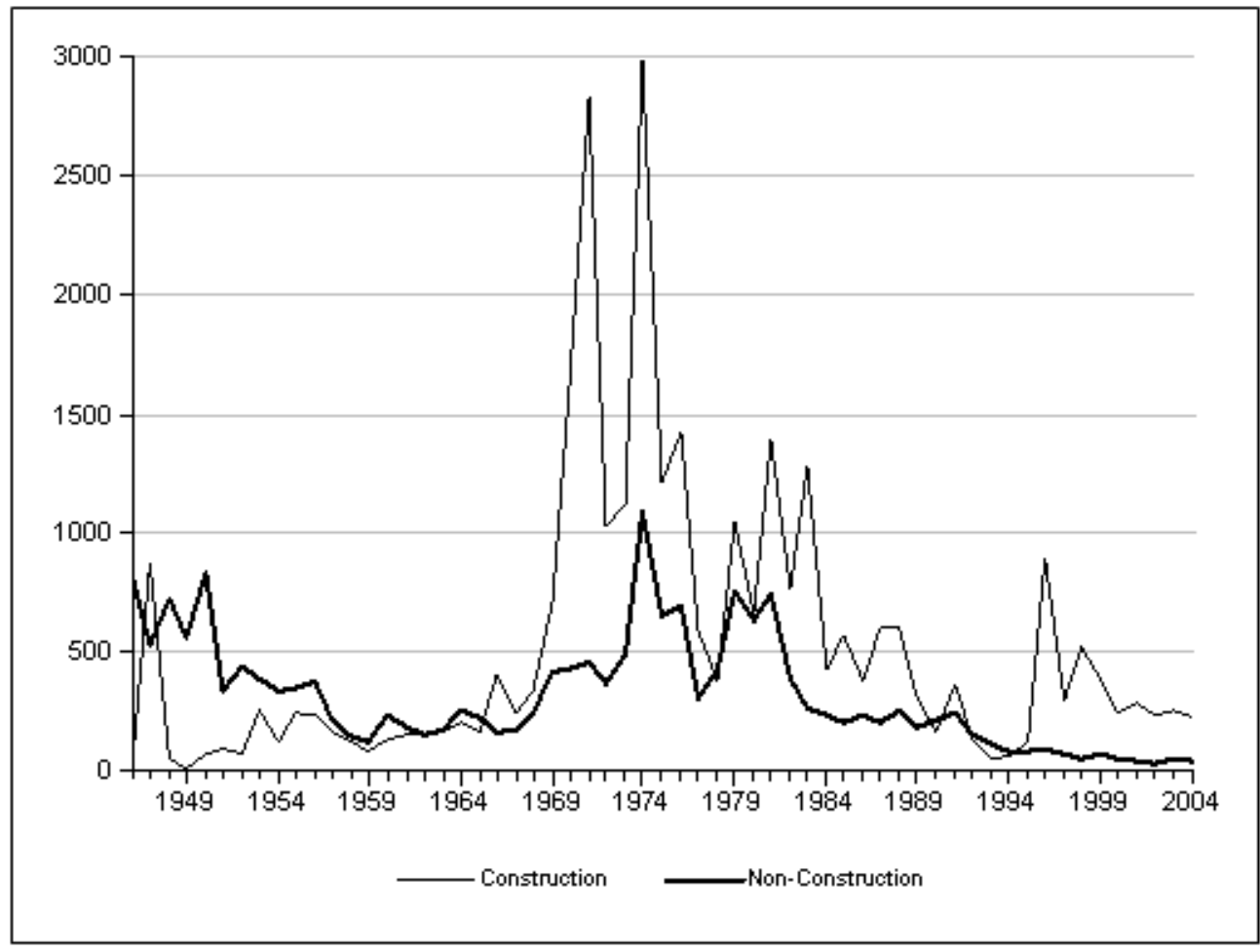

Figure 1: Strike Activity: Construction and Non-Construction Sectors Working Days Lost per Sector Employee, Sources: See Data Sources Appendix

\footnotetext{
${ }^{8}$ See RCBCI (2002a, 2002b, 2002c)
} 
The post-World War II period can be divided into four very broad phases.

The first phase extends from 1946 to around 1956. During this period the overall level of industrial disputes was relatively high on average. This did not apply, though, to the same extent for the Construction sector, wherein the strike rate was less than half that for the overall economy (see Figure 1).
Another way of viewing the changing pattern of the relative significance of strikes in the construction sector is to calculate the proportion of construction strikes to total strikes. Figure 2 does this. It indicates that during this first phase, strikes in the construction sector accounted for a relatively small fraction (4 per cent on average) of total strikes. Mining, manufacturing and transport (particularly stevedoring) were the principal generators of strikes during this phase.

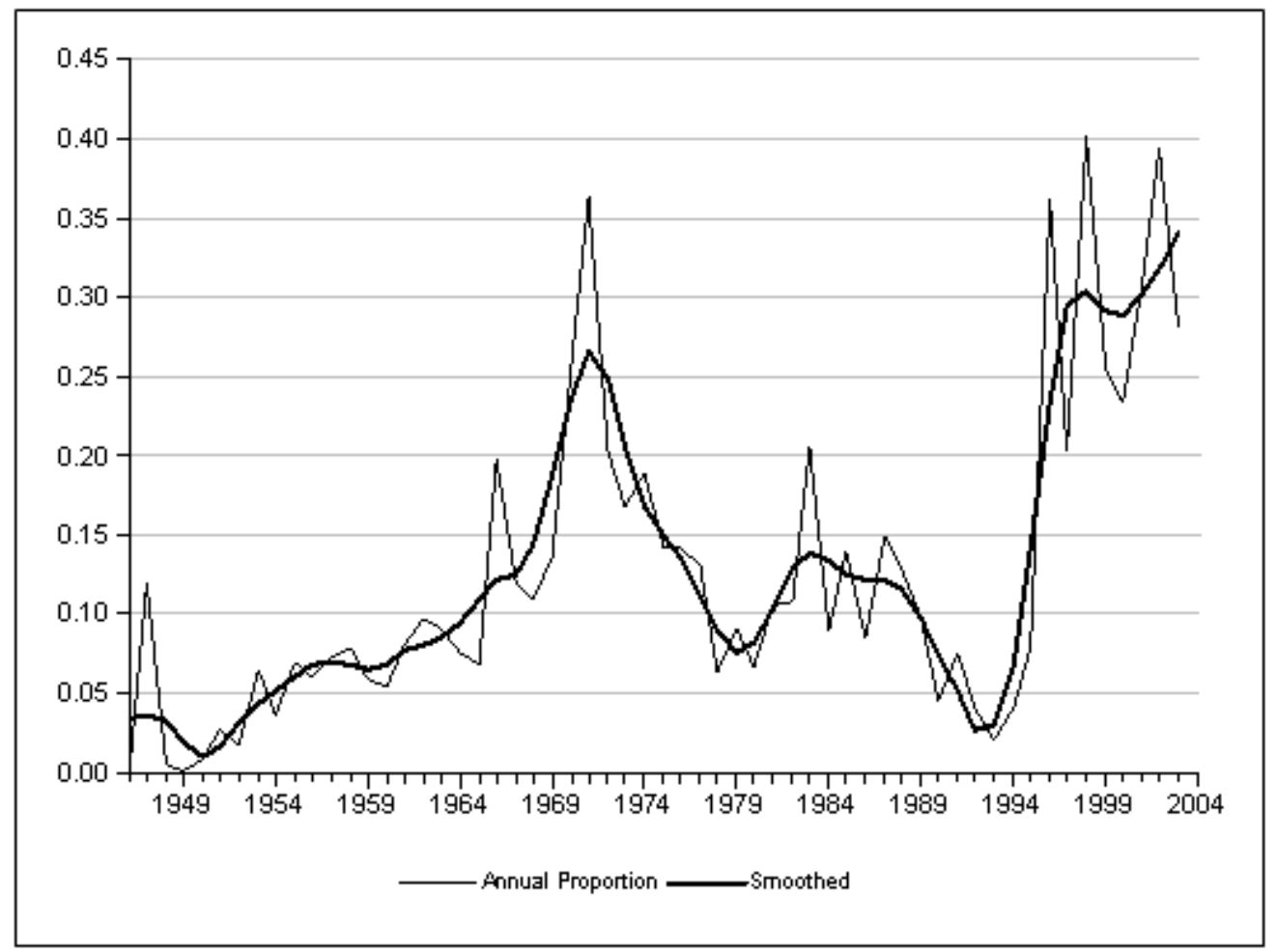

Figure 2: Strike Activity: Construction as a Proportion of Total Working Days Lost,

Sources: See Data Sources Appendix

This first phase was marked by relatively low unemployment and, perhaps more importantly, relatively high inflation. The inflation was linked, in turn, to (i) the effect of relaxing post-war restrictions on spending and (ii) excess demand pressures associated with the Korean War (1950-53), among other things. It was also a period of considerable global and local ideological tension between the supporters of communism versus capitalism. Communists often dominated union leadership positions and were perceived, rightly or wrongly, to be intent on disrupting the orderly operations of society. The Communist Party dissolution bill was introduced to destroy the Communist Party. The attempted introduction of this legislation was emblematic of the hostilities present at the time. Initially introduced in 1950, it was found by the High Court to be unconstitutional. When re-introduced as an amendment to the Constitution in 1951, it was again defeated - although only narrowly.

The second phase extends from around 1957 to 1966 . During this period the overall level of industrial disputes was relatively low on average. Strike activity in the construction sector was by now starting to match and, by 
the end of this period, surpass that of the overall economy (Figure 1). During this first phase, strikes in the construction sector accounted on average for 9 per cent of total strikes Like the first phase, the second phase was marked by low unemployment compared to recent experience, but higher unemployment than during the (rather exceptional, so far as the unemployment rate is concerned) first phase. Inflation during the second phase was relatively mild, averaging around 2.5 per cent per annum.

The third phase extends from around 1967 to around 1982. During this period the overall level of industrial disputes was relatively high on average - similar on average to the rate experienced during the first phase. The strike rate in the construction sector was, on average, about twice that for the economy as a whole. The early and mid1970s were particularly strike prone for the Construction sector. Never in Australia's recorded history has the level of strike activity in the construction sector been as high as it was during 1971 and 1974. This phase was marked by the emergence of stagflation, the simultaneous presence of relatively high inflation and unemployment rates. The worldwide inflation of this period was linked to the monetary expansion devised to finance the Vietnam War, major oil price rises in 1973 and 1979, the gradual embedding of inflationary expectations and, perhaps, the early unresponsiveness of wages and earnings to high unemployment rates. This was also a period of considerable social unrest during the earlier years of this phase. The Vietnam War, in which Australia had committed troops in support of US attempts to hold back a communist takeover, was bitterly opposed by a sizeable (and increasing) portion of the population. ${ }^{9}$

\footnotetext{
${ }^{9}$ Conscription, both here and in the USA, was particularly divisive and unpopular. Australian involvement in the Vietnam War lasted from 1962 to 1972 . This initially involved a small number of advisors. In 1965 the Menzies government committed a battalion, and in 1966 the Holt government increased troop numbers including conscripts. The year in which the first conscript died in Vietnam was 1966. Mass demonstrations, both here and abroad, became an ever increasing feature of the political landscape. The last of the Australian mass rallies against conscription was in 1971 and attracted over a 100,000 demonstrators. By this time, both here and overseas, public support for the military campaign was waning as troops were progressively withdrawn.
}

The fourth phase extends from around 1983 to around 2004. During this period the overall level of industrial disputes was relatively low on average and generally falling. The unemployment rate was relatively high on average. Inflation, on the other hand, was relatively low. Indeed, for each of the four suggested phases of differing average levels of industrial disputes, there have been reasonably similar average levels of price-level instability. This is reflected in Figure 3 which charts inflation and strike activity levels in terms of index values and compares the average values for each of the phases. Broadly speaking, during phases when strikes tended to be relatively high, inflation on average also tended to be relatively high. As Figure 3 indicates, the latest phase of relatively low strike rates, has been associated with relatively low rates of inflation - at least on average. From 1983 to 1996 the labour government pursued an incomes policy of sorts, referred to as the Accord. The Accord changed quite significantly over its period of currency from a centralised arrangement initially established to maintain employee's income levels, to a relatively decentralised arrangement designed to encourage enterprise bargaining and wage changes linked to enterprise productivity improvements. In 1996 the newly-elected Howard Coalition government reinforced this decentralising policy direction by legislatively reducing the role of unions in the bargaining process and encouraging individual one-onone employee-employer workplace agreements. Strikes in the construction sector were lower on average than during the preceding phase. However their proportional significance rose as Figure 2 indicates. 


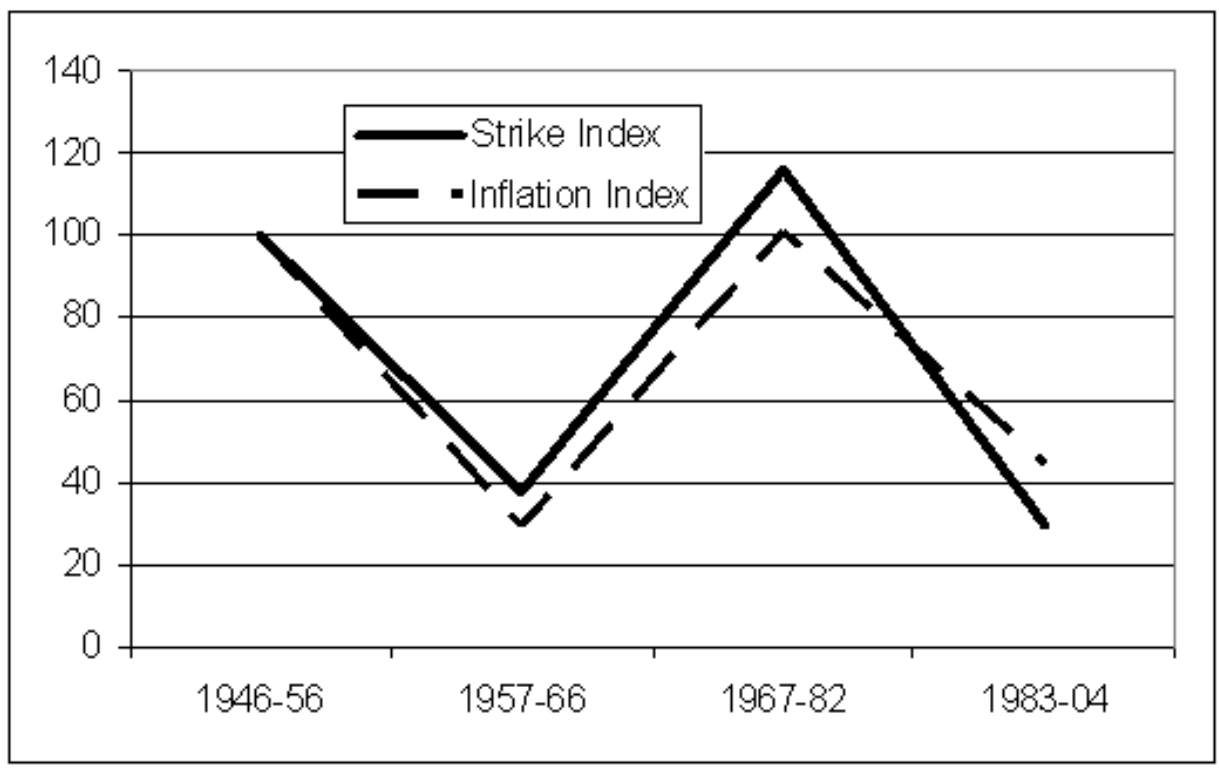

Figure 3: Strike Activity and Inflation Index Values: 1946-56=100, Sources: See Data Sources Appendix

What factors have been seen to be responsible for changing industrial dispute rates over the years? More recent research has sought to explain the declining incidence of disputes. Factors that have been found or argued to be important include: (i) declining inflation (Morris and Wilson, 1999; Perry, 2004; Hodgkinson and Perera, 2004), ${ }^{10}$ (ii) declining union membership (Morris and Wilson, 1999; Healy, 2002; Perry, 2004) and (iii) changing legislative and/or administrative arrangements (Morris and Wilson, 1999; Healy, 2002; Hodgkinson and Perera, 2004). It should also be noted that the decline in industrial disputes in Australia over the last couple of decades or so is not unique, it is a worldwide phenomenon (Perry and Wilson, 2001,2004 ) of which Australia arguably is but a small part.

What about industrial disputes in the construction sector? What factors have been seen to be responsible for changes here? No econometric research has as yet been carried out on this specific sector. Analysis and commentary has tended to rely on a visual inspection of the data for different time frames. Three discussion papers in the Cole

\footnotetext{
${ }^{10}$ Recall Figure 3 graphs the average value of the strike rate and inflation for the afore-discussed four suggested phases of strikes. The graph suggests a positive longer-term average association between these variables.
}

Commission (numbers 2, 3 and 17) have focussed on the underlying descriptive characteristics of construction-sector strikes. For example strikes in the construction sector have tended to be higher than for the economy as a whole (Figure 1). In fact this has been a central concern for the Cole Commission and its supporters. Other data are not particularly instructive, as they tend to be related to either a short period of time or are unexceptional.

The Cole Commission attributes the relatively high incidence of industrial disputes to the actions and idiosyncrasies of the CFMEU in its current and past incarnations (the BWIU). The Cole Commission argues that the militant and unlawful industrial actions of the CFMEU need to be curbed through the implementation of tougher workplace relations legislation specifically designed for the construction industry.

In a recent Senate hearing on the Cole Report and the proposed legislative changes that spring from it, the suggestion was advanced, in reference to the relatively high incidence of disputes, that workers and unions are relatively sensitive to safety issues and prepared to take strike action when safety issues are not addressed (Official Committee Hansard, 2004). 
Dabscheck (2003) points out that the Cole Commission argues, on the one hand, that safety issues are of paramount importance, but spends a relatively small amount of time dealing with the issue. Between 1995 and 2000 there was on average about one death per week in the industry due to accidents, and about 55 non-fatal accidents per week. He queries why none of the employers of the deceased workers were specifically quizzed by the Royal Commission about the circumstances behind these personal tragedies (Official Committee Hansard, 2004). He further notes that:

\begin{abstract}
'Another reason the [strike] figures might be a little bit higher in this industry than in others is that in Victoria when a worker dies there is a state-wide strike - the royal commissioner said that, from memory. $\mathrm{He}$ criticised that. That is an interesting thing to think about'
\end{abstract}

While it may be true that safety issues, injuries and deaths have contributed directly and indirectly to relatively high strike rates in construction, the question might be asked: why was the relative incidence of strikes in earlier eras (noted above) lower? Were safety issues less important in those years? It would be instructive to review historical time series on these and related issues, if such information is accessible.

\section{CONCLUDING COMMENTS}

This paper has identified, among other things, the changing pattern of industrial disputes in the Australian construction sector relative to the rest of the economy. It has

\section{Data Sources Appendix}

Australian Bureau of Statistics (ABS) Industrial Disputes, Cat. No. 6321.0 various issues and predecessor publications; ABS Labour Force Australia, Cat. No. 6202.0 various issues and predecessor publications; AusStat-related spreadsheets:

6321.0.55.001 Industrial Disputes, Australia. Inflation is measured by the annual percentage change in the GDP deflator. shown that the strike rate in the construction sector has, on average, been greater than the strike rate for the rest of the economy. In spite of this, there has been a marked longterm declining trend in the pattern of industrial disputes in the construction sector during the second half of the post-war period. To be sure, the strike rate has picked up at times, for example during the early 1980s and the mid-1990s, but the long run downward trend is indisputable.

Interestingly, it was during the period of the Accord that the strike rate for the construction fell to its lowest level since the 1940s. Perhaps the mix of policies employed during this period of consultation and consensus, coupled with the major recession in the early 1990s, produced that interlude of relative quiet. The apparent success of the Accord in lowering the strike rate leaves one to wonder whether a policy along the lines of the Accord is better suited as a stratagem for reducing conflict in this sector. It also leads one to question whether the Cole Commission's strategy of attacking the union movement in the construction sector is going to be the most effective way of resolving tensions in the industry. We may soon find out.

It has been argued by some observers that the relatively high strike rate in the construction sector has been attributable to the weak safety record of the industry. This is an area that has not been, as far as the author is aware, systematically analysed, which is unfortunate because it is a very important issue. The issue of safety and its effect on strikes is an area where further research is definitely warranted.

Source: ABS, TRYM Model Database, Econdata.

\section{REFERENCES}

ABS (2005a). National Accounts: National Income, Expenditure and Product, 5206.0, Australian Bureau of Statistics, December 2004.

ABS (2005b). Labour Force, Australia, Cube Table E06, Employed Persons by Sex, Industry, State, Status in Employment, 
Australian Bureau of Statistics, Feb 2005, 6291.0.55.001. (Electronically delivered data)

ABS (2005c). Employee Earnings, Benefits and Trade Union Membership, 6310.0, Australian Bureau of Statistics, August 2004.

Andrews, K. (2004). Andrews criticises Labor's workplace policies. Insiders, ABC TV Program Transcript, Broadcast 4 July 2004, http://www.abc.net.au/insiders/content/2004/ s1146360.htm

Briggs, C. (2004). The Return of the Lockout in Australia: a Profile of Lockouts since the Decentralisation of Bargaining. Australian Bulletin of Labour, 30(2), 101-112.

Cole Royal Commission (2003). Final Report of the Royal Commission into the Building and Construction Industry. Volumes 1-22, Commonwealth of Australia, Canberra.

Dabscheck, B. (2003). Two and Two Make Five: Industrial Relations and the Gentle Art of Double Think. The Sir Richard Kirby Lecture to The Industrial Relations Society of Victoria, Melbourne, 20 August.

http://www.cfmeu.asn.au/construction/pdfs/T heKirbyLecture.pdf

Healy, J. (2002). Peace at Last: Recent Trends in Australia's Industrial Action. The Australian Bulletin of Labour, 28(2), 80-87.

Hodgkinson, A. and Perera, N. (2004). Strike Activity Under Enterprise Bargaining: Economics or Politics. Australian Journal of Labour Economics, 7(4), 439-457.

Marr, J. (2003). First the Verdict: The Real Story of the Building Industry Royal Commission, Pluto Press, Annandale.

Maitland, J. (2004). Paper by John Maitland to the AFR Conference on Industrial Relations Reform 2005.

http://www.cfmeu.asn.au/national/curr_affair s/files/IR\%20REFORM\%202005.doc

Moore, D (2004). .Overmighty Judges: 100 Years Of Holy Grail Is Enough. Presentation to the H. R. Nicholls Society, XXV Conference, Melbourne, 6-8 August. http://www.ipe.net.au/hrnpaper04.html
Morris, A. and Wilson, K. (1999). Industrial disputes and the Accord: A Final Word. Australian Bulletin of Labour, 25, 63-71.

Official Committee Hansard (2004) Senate Employment, Workplace Relations and Education Reference Committee, Commonwealth of Australia. Wednesday, 7 April.http://www.aph.gov.au/hansard/senate/ commttee/S7498.pdf.

Perry, L. J. (2004). Comments on the Decline in Strikes in Australia. Australian Bulletin of Labour, 30(2), 134-148.

Perry, L. J. and Wilson, Patrick J. (2001). The Accord and Industrial Disputes: An International Perspective. Australian Journal of Labour Economics, Vol. 4, No. 4, pp. 232247.

Perry, L. J. and Wilson, Patrick J. (2004). Trends in Work Stoppages: A Global Perspective. Working Paper No. 47, November, Policy Integration Department, Statistical Development and Analysis Unit, International Labour Office.

http://www.ilo.org/public/english/bureau/integ ration/departme/about/working.htm

Perry, L. J. (2005). Productivity and Industrial Disputes: A Note on the Cole Royal Commission. Economic Papers, Forthcoming.

RCBCl (2002a). Statistical Compendium for the Building and Construction Industry. Discussion Paper 2, Royal Commission into the Building and Construction Industry.

RCBCl (2002b). Productivity and Performance in the Building and Construction Industry. Discussion Paper 3, Royal Commission into the Building and Construction Industry.

RCBCl (2002c). Productivity and the Building and Construction Industry. Discussion Paper 17, Paper prepared by Tasman Economics for the Royal Commission into the Building and Construction Industry.

Skully, M. and L. Tingle (2005). Howard takes charge of IR reform. Australian Financial Review, 16 May, 1 \& 4. 